\title{
ARTEFAK LITIK DI KAWASAN PRASEJARAH BATU EJAYYA: TEKNOLOGI PERALATAN TOALIAN DI PESISIR SELATAN SULAWESI
}

\author{
The Lithic Artefact at Batu Ejayya Prehistoric Region: The Technology \\ of Toalian Tools in Southern Coast of Sulawesi
}

\author{
Suryatman \\ Balai Arkeologi Sulawesi Selatan \\ J1. Pajjaiyang No. 13 Sudiang Raya Makassar, Indonesia \\ suryatman.arkeologi@gmail.com
}

Naskah diterima: 02/12/2016; direvisi: 21/05-07/06/2017; disetujui: 09/06/2017

Publikasi ejurnal: 29/06/2017

\begin{abstract}
The Batu Ejayya region records prehistoric Toalian occupation between the mid and late Holocene near the south coast of South Sulawesi. This region is located in a volcanic rock formation, where available Chert sources are difficult to find. The research problem is the behavior of the Toalian occupants in the region in making well adapted lithic tools in view of the limited availability of Chert. The lithic artifacts found on the surface and during excavation are analyzed focusing on the categories of retouched flake tools, unretouched flake tools, complete flakes, and cores on Chert and volcanic stone. The results show that the production of small tools had stringent and complicated needs, requiring the Toalians to search out and find Chert as the main ingredient. Stages in the technology for utilizing Chert resource began with reduction of geological nodules far from where the sites were located. Volcanic stone was used as an alternative raw material only for making large tools that required little in the way of modification.

Keyword: Toalian, Technology, Source, Behavior, Batu Ejayya Region.
\end{abstract}

\begin{abstract}
Abstrak
Batu Ejayya adalah salah satu kawasan prasejarah hunian Toalian di pesisir selatan Sulawesi. Kawasan ini mulai dihuni pada masa pertengahan hingga akhir holosen. Kawasan tersebut berada di wilayah formasi batuan Vulkanik, dimana ketersediaan sumber bahan Chert untuk peralatan sulit ditemukan. Permasalahan penelitiannya adalah bagaimana perilaku penghuni Toalian membuat peralatan litik dengan keterbatasan bahan material berkualitas baik di sekitar kawasan situs. Temuan artefak litik dari ekskavasi dan survei akan dianalisis dengan fokus pada kategori alat serpih diretus, serpih tidak diretus, serpih utuh dan batu inti pada bahan batuan Chert dan Vulkanik. Hasil penelitian menunjukkan bahwa kebutuhan peralatan kecil yang cenderung tinggi dan rumit mengharuskan mereka untuk mencari dan menemukan bahan tersebut sebagai bahan utama. Tahapan teknologi untuk bahan Chert diawali dengan penyerpihan awal yang dilakukan diluar dari kawasan situs. Bahan Vulkanik hanya sebagai bahan alternatif untuk peralatan berukuran besar dan tidak membutuhkan modifikasi tinggi.
\end{abstract}

Kata Kunci: Toalian, Teknologi, Bahan Material, Perilaku, Kawasan Batu Ejayya.

\section{PENDAHULUAN}

Toalian (Toalean atau Toala) adalah istilah yang digunakan oleh sebagian besar peneliti untuk menyebut budaya artefak litik yang muncul pada masa antara awal hingga akhir holosen di Sulawesi Selatan. Kehadiran peralatan Lancipan Maros dan Geometrik Mikrolit berkonteks dengan temuan serpih-serpih berbentuk Bilah menunjukkan bahwa Toalian adalah sebuah tekhnokompleks Serpih Bilah yang khas di wilayah Kepulauan Asia Tenggara (Bellwood, 2007:193-196).

Heekeren (1972) meyusun fase teknologi Toalian dari penggalian Callenfels di Batu Ejayya pada tahun 1937 dan dibandingkan dengan artefak lainnya pada 20 situs yang berbeda (Soejono, 1984: 142, Heekeren, 1972; 111-115). Fase tersebut terdiri dari tiga tahapan, yakni Toala Awal 


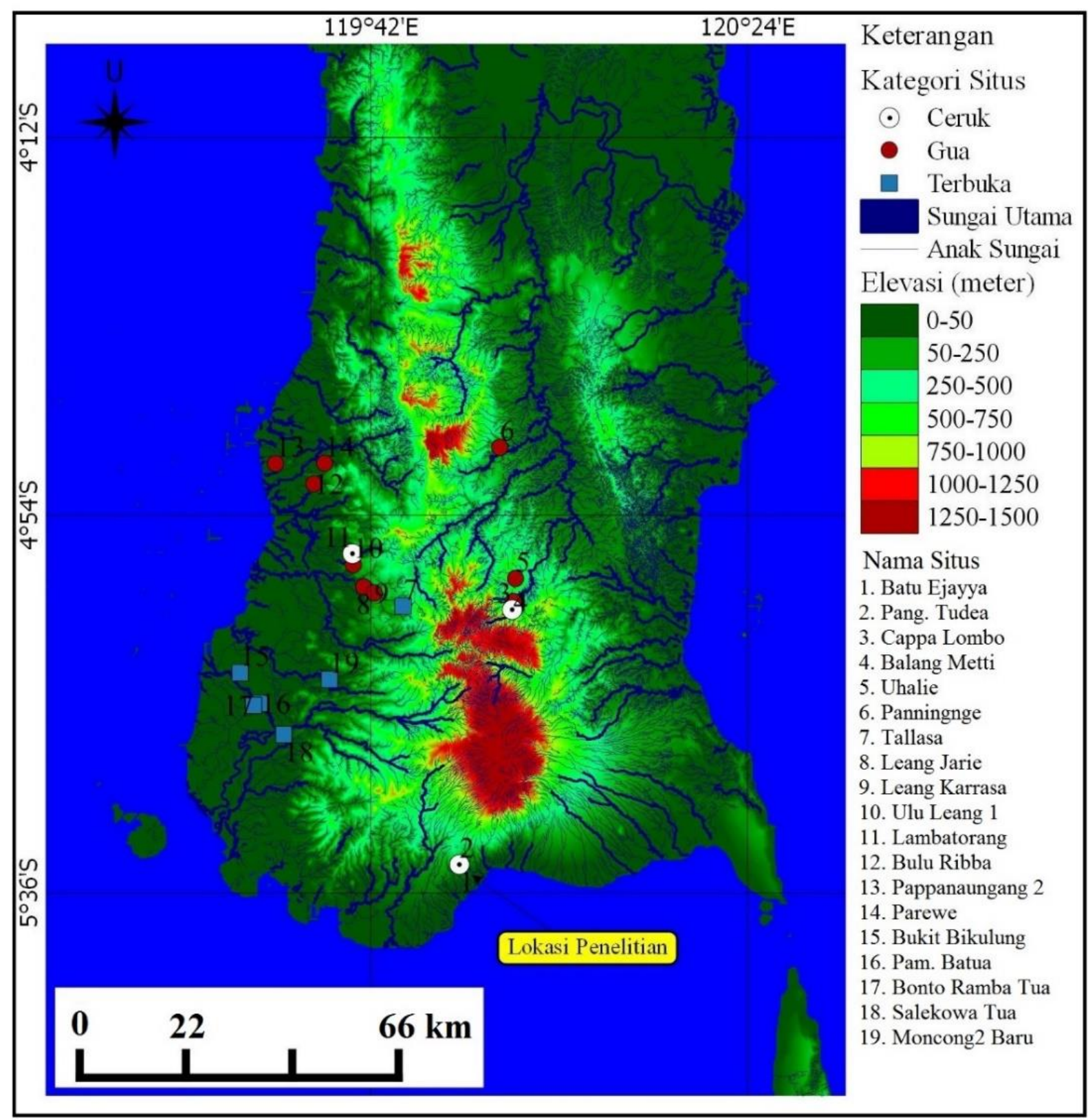

Gambar 1. Peta Situs-situs hunian Toalian yang dirangkum dari hasil Penelitian sebelumnya.

(Sumber: SRTM Sulawesi Selatan 2014 dan

Badan Informasi Geofasial 2012, dengan modifikasi)

bercirikan serpih dan bilah yang agak kasar dan besar yang diantaranya serpih berujung cekung dan bilah berpunggung, Toala Tengah bercirikan bilah, mata panah perpangkal bundar dan alat-alat mikrolit dan Toala Akhir bercirikan alat serpih mata panah bersayap dan bergerigi, lancipan muduk, serut kerang dan tembikar (Heekeren, 1972; 111-115). Namun demikian, fase hunian tersebut tidak didukung oleh data stratigrafi dan pertanggalan.

Data lengkap ditunjukkan oleh Glover (1976) dari penggaliannya di Situs Ulu Leang 1, di kawasan gua-gua karts Maros. Hasil penelitan tersebut menunjukkan bahwa pertanggalan tertua teknologi Toalian diperkirakan berlangsung antara 8000-7000 BP. Namun teknologi lancipan maros dan geometrik mikrolit 
diperkirakan dikenal pada masa antara 55003500 BP (Glover 1976:113-115; 1978:60101).

Situs-situs hunian Toalian ditemukan tersebar di sebagian besar daerah pesisir barat daya Sulawesi Selatan. Bulbeck (1992) melaporkan beberapa temuan peralatan Toalian di situs-situs terbuka lainnya. Lokasi situs tidak jauh dari sungai Jeneberang dan Tallok daerah Takalar dan Makassar. Situs-situs tersebut diantaranya adalah Situs Pamangkulang Batua, Bukit Bikulung, Salekowa Tua, MoncongMoncong Baru, Pakka Mukang, Balang Sari, Bonto Ramba Tua, Saukang Boe, Gentung, dan Bonto Sunggu Asli. Beberapa temuan yang dilaporkan adalah lancipan maros, mikrolit dan serpihan berbentuk bilah. Pengambilan sampel pertanggalan dari kerang juga dilakukan di perkampungan Bone-bone (tidak jauh dari Situs Bukit Bikulung) dan menghasilkan umur 59906390 cal. BP (ANU-5925) (Bulbeck, 1992; Pasqua, 1995; Bulbeck, Pasqua dan Di Lello, 2000).

Beberapa situs lain dengan temuan peralatan Toalian juga dilaporkan dari beberapa penelitian Balai Arkeologi Sulawesi Selatan (Balar Sulsel) di bagian timur Kabupaten Maros dan bagian barat daya Kabupaten Bone (gambar 1). Situssitus tersebut adalah Situs Tallasa di Kecamatan Simbang, Kabupaten Maros, Situs Panningge di Kecamatan Mallawa Kabupaten Maros dan Situs Ballang Metti 1 di Kecamatan Bontocani, Kabupaten Bone.

Sebaran situs-situs Toalian di bagian barat terlihat didominasi oleh gua-gua dari formasi gugusan gamping karts Maros Pangkep sedangkan di bagian barat daya adalah situs terbuka, umumnya tidak jauh dari daerah aliran sungai Jeneberang. Di bagian tengah, lokasi situs-situs Toalian berada di dataran tinggi Sulawesi dan tidak jauh dari Sungai Walennae. Lokasi tersebut sebagian besar adalah gua dan ceruk yang umumnya berada pada formasi batuaan gamping tonasa.
Di pesisir selatan, peralatan Toalian hanya ditemukan di Kawasan prasejarah Batu Ejayya. Kawasan ini terpisah jauh dengan himpunan situs lainnya di sebelah barat dan barat daya Sulawesi. Bulbeck telah menunjukkan pertanggalan dari Situs Batu Ejayya dengan kisaran umur 4700 hingga 4300 cal. BP (Bulbeck, Pasqua dan Di Lello, 2000; 71-108).

Kawasan Batu Ejayya berada di wilayah formasi geologi batuan Vulkanik, berasal dari hasil erupsi gunung api Lampobattang. Formasi tersebut menunjukkan bahwa material Chert akan sulit ditemukan di sekitar situs. Berbeda halnya dengan kawasan situs lain, dimana secara umum berada di wilayah formasi gamping dengan ketersedian sumber Chert (Gamping Kersikan) cukup melimpah. Keterbatasan bahan material akan berdampak terhadap perilaku manusia penghuni Toalian di kawasan ini.

Chert adalah bahan berkualitas baik dan umumnya digunakan dalam teknologi alat batu Toalian. Permasalahan penelitian dalam tulisan ini bagaimana perilaku penghuni teknologi membuat peralatan litik di Batu Ejayya dengan keterbatasan bahan material di sekitar kawasan situs? Dari permasalahan tersebut, maka tulisan ini bertujuan untuk menunjukkan tingkah laku penghuni Toalian di pesisir selatan Sulawesi dalam menghadapi situasi tersebut.

\section{METODE PENELITIAN}

Data yang digunakan untuk analisis adalah hasil penelitian terbaru Balar Sulsel tahun 2017 di Kawasan Batu Ejayya. Data artefak litik berasal dari penggalian di Situs Pannganikang, salah satu situs di kawasan Batu Ejayya. Selain data ekskavasi, data lain digunakan adalah temuan survei di beberapa situs lainnya yaitu di Situs Batu Ejayya, Bulu Saraung, Panganreang Tudea, Pangganikang dan Pattenungang. Data ekskavasi dianggap tidak representatif mewakili interpretasi data karena jumlah yang cenderung sedikit. Oleh karena itu 
temuan permukaan diperlukan sebagai tambahan data.

Sampel temuan litik yang dipilih terdiri dari beberapa kategori yaitu, Alat Serpih Diretus (Retouched Flake Tools), Alat Serpih tidak Diretus (Unretuched/Utilized Flake Tools), Serpih Utuh (Complete Flake), dan Batu Inti (Core). Alat Serpih Diretus adalah alat serpih dari serpih yang diproses atau dikerjakan ulang (Secondary Working) dengan cara diretus atau dirapikan pada sisi tajaman untuk menghasilkan tipe alat sesuai keinginan sipembuat alat. Alat Serpih tidak Diretus adalah alat dari serpih yang tidak memperlihatkan ada pengerjaan ulang (Primary Working), namun memperlihatkan indikasi penggunaan pada sisi tajaman. Indikasi penggunaan berupa kerusakan tajaman (Usewaer), kilapan (Gloss) dan residu (Residue). Serpih Utuh adalah serpihan (Debitage) dari hasil penyerpihan langsung dengan pelepasan yang tidak mengalami kegagalan seperti pelepasan lurus (Feather Termination), bergantung (Hinge Termination), dan melengkung

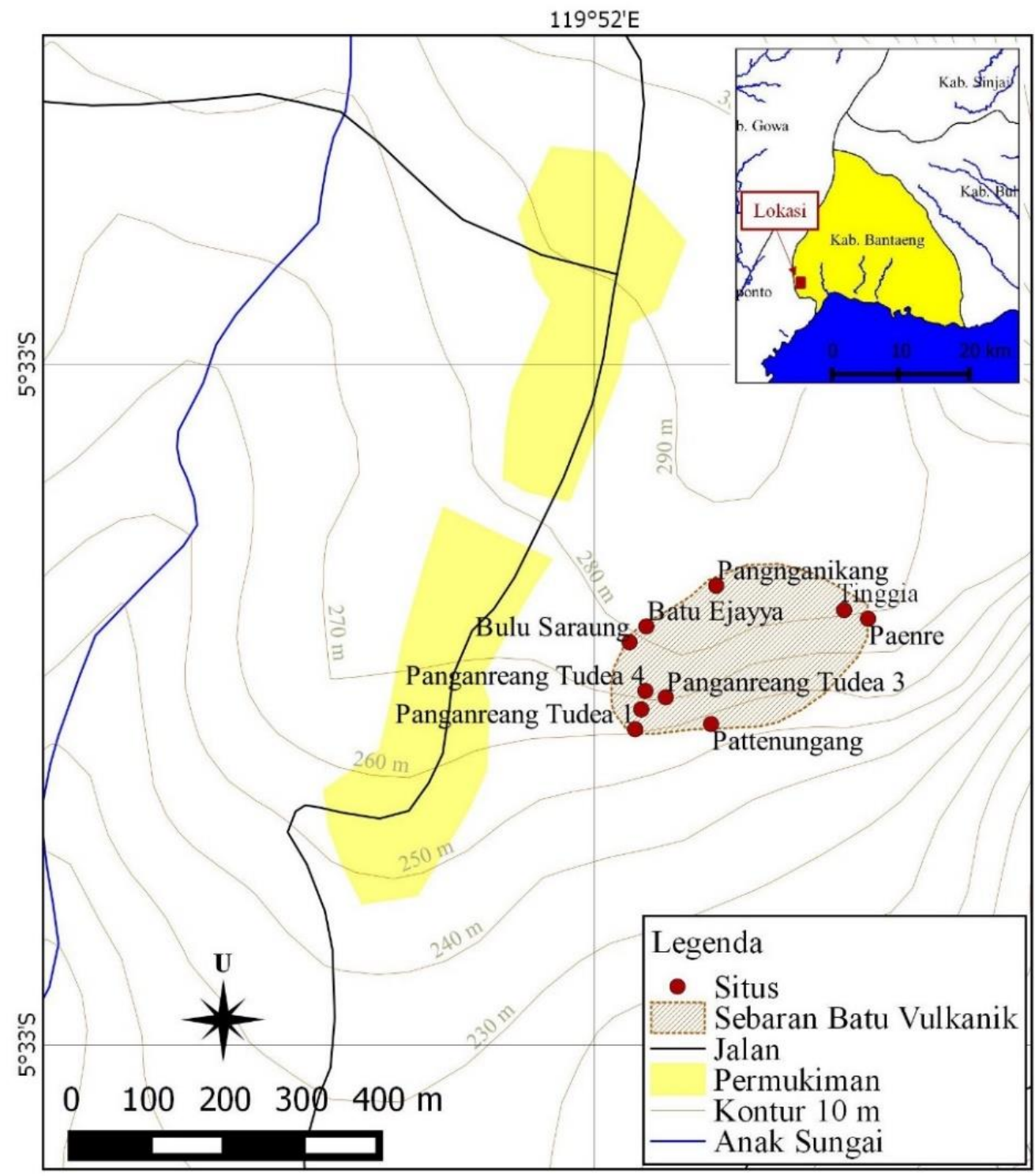

Gambar 2. Lokasi situs-situs di Kawasan Prasejarah Batu Ejayya (Sumber: Dokumentasi Balar Sulsel, Tahun 2017) 
(Plunging Termination) (Andrefsky, 2005: 127-129). Batu Inti adalah artefak batu yang digunakan sebagai penghasil serpih (Creator of Flake) dengan indikasi negatif bulbus dan luka pukul (Flake Scars) pada sisi artefak (Hiscock, 2007: 198-220).

Artefak litik akan diklasifikasi berdasarkan bahan material. Semua kategori artefak litik akan diukur panjang, lebar, tebal dan berat artefak. Untuk kategori Alat Serpih Diretus, tidak Diretus dan Serpih Utuh akan diukur lebar dan tebal dataran pukul (Striking Platform) apabila masih memiliki dataran pukul. Semua kategori Batu Inti akan dihitung dan diukur panjang pelepasan serpih (Flake Scars) yang tampak pada semua sisi. Data selanjutnya akan dianalisis lebih lanjut dengan cara menyajikan ringkasan dan komparasi data pada setiap varibel menggunakan aplikasi statistik $R$ Studio versi 3.0.1.

\section{HASIL DAN PEMBAHASAN}

\section{Deskripsi Situs di Kawasan Prasejarah Batu Ejayya}

Kawasan Prasejarah Batu Ejayya secara administratif berada di Kelurahan Bonto Jaya, Kecamatan Bissapu, Kabupaten Bantaeng, Sulawesi Selatan. Secara astronomis, Kawasan Prasejarah Batu Ejayya terletak pada titik $5^{\circ} 32^{\prime} 49,7^{\prime}$ ' LS dan $119^{\circ} 51^{\prime} 52,8^{\prime}$ ' BT dengan ketinggian 303 meter dari permukaan laut. Survei pada tahun 2012 menunjukkan 10 situs yang berpotensi dihuni yaitu Situs Batu Ejaya, Bulu Saraung, Leang Panganrea Tudea 1, 2, 3, dan 4, pattenungang, Pangganikang, Leang Tinggia 1 dan dan Paenre (gambar 2). Situs berupa gua hanya Situs Batu ejayya, Panganreang Tudea 3 dan Panganreang Tudea 4, sedangkan situs lainnya adalah ceruk.

Kawasan Batu Ejayya adalah gugusan batuan gunung api, terdiri dari bongkahan dan bolder dengan luas mencapai $\pm 1 \mathrm{~km}^{2}$ (gambar 4 dan 5). Luas batuan tersebut menyebar hingga mencapai $\pm 4 \mathrm{~km}^{2}$. Batuan berasal dari bahan Vulkanik formasi batuan gunung api hasil erupsi parasit, terbentuk pada kala Pleistosen. Luas areal formasi ini mencapai $102 \mathrm{~km}^{2}$ di sebagian besar wilayah Kabupaten Bantaeng. Di sebelah utara formasi tersebut membentang luas areal formasi batuan gunung api Lampobattang, terdiri dari batuan konglomerat, lava, breksi endapan lahar dan tufa (gambar 3). Di sebelah barat laut adalah formasi batuan gunung api Batu RapeCindoko, terdiri dari jenis batuan lava, breksi tufa dan konglomerat. Formasi Camba terlihat sekitar $7 \mathrm{~km}$ sebelah barat wilayah formasi erupsi parasit. Formasi ini berasal dari batuan sedimen laut berselingan batuan gunung api.

Penelitian di Kawasan Prasejarah Batu Ejayya mulai dilakukan pada tahun 1937 di Situs Batu Ejayya dan Panganreang Tudea oleh Stain van Callenfels. Penggalian dilanjutkan oleh Mulvaney dan Soejono pada tahun 1970 di Situs Batu Ejayya 1, Batu Ejayya 2 dan Batu Tuda. Situs Batu Tuda yang dimaksud dalam penelitian sebelumnya adalah Situs Pangnganikang. Hal ini berdasarkan informasi oleh seorang warga mengenai penggalian yang pernah dilakukan oleh orang asing di depan Situs Pangnganikang pada tahun yang sama (Nama Informan: Sanusi, Umur: 60 tahun). Bulbeck (1997) mengambil dua sampel pertanggalan berupa kerang dari penggalian kotak 1 spit 5 dan kotak 2 spit 1. Pertanggalan dari sampel kerang menunjukkan kisaran umur 4420-4780 cal. BP dan 4320-4705 cal. BP (Bulbeck, Pasqua dan Di lello, 2000; 71-108).

Penggalian dilanjutkan pada tahun 2012 dan 2013 di Situs Batu Ejayya, Panganreang Tudea dan Pattenungan (Balar Sulsel 2012; 2013). Penggalian di Situs Batu Ejayya menunjukkan lapisan hunian pratembikar dengan indikasi temuan berupa artefak litik yang didominasi oleh bahan Vulkanik. Pada lapisan atas ditemukan layer tembikar dengan indikasi temuan berupa fragmen tembikar dan artefak litik. Bahan 


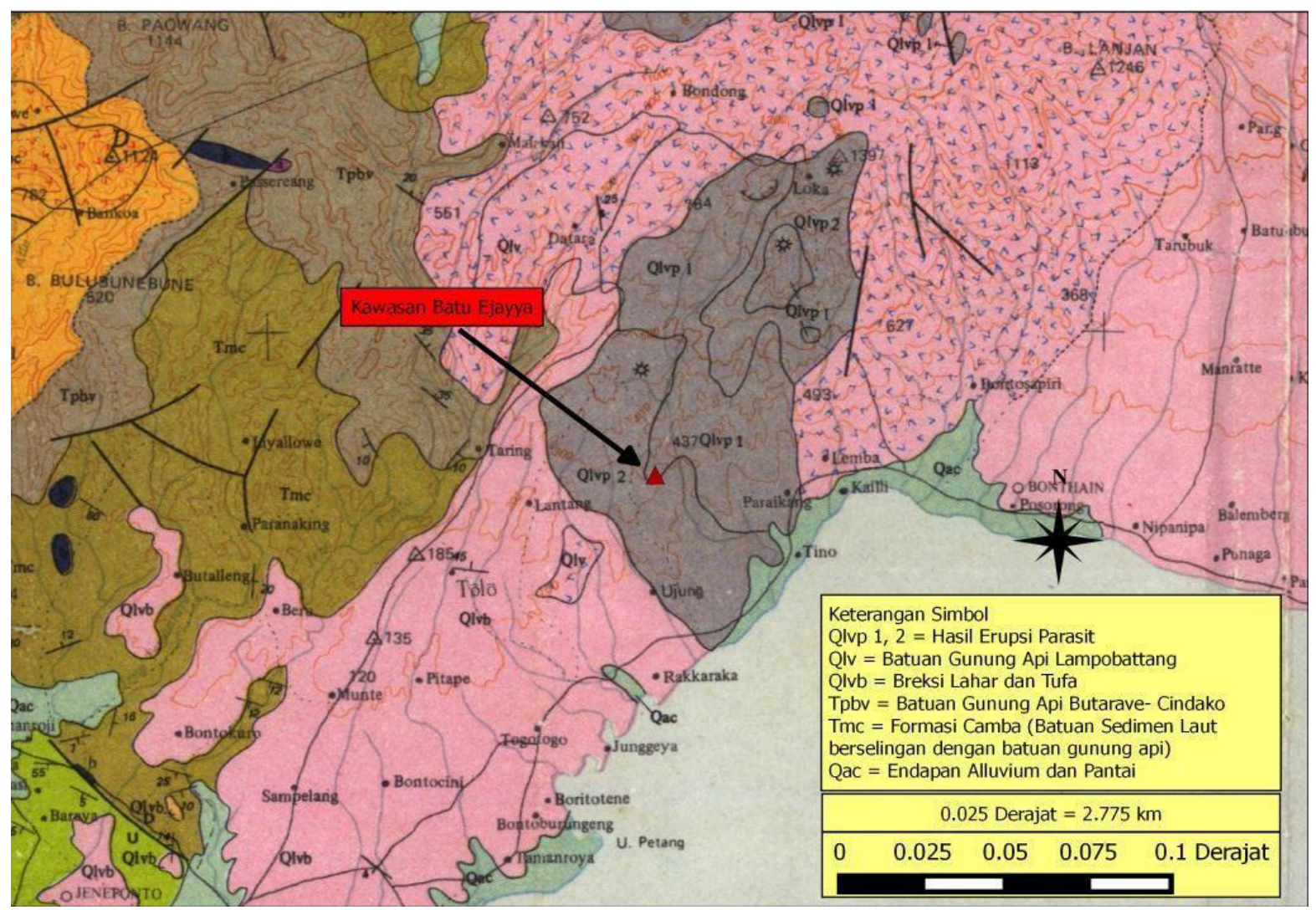

Gambar 3. Peta Geologi di sekitar wilayah Kawasan Batu Ejayya

(Sumber: Dikutip dari Peta Geologi Bersistem Indonesia, lembar Ujung Pandang, Bentaeng, Sinjai, Skala 1 : 250.000, oleh Ram Sukamto dan Sam Supriatna tahun 1982).
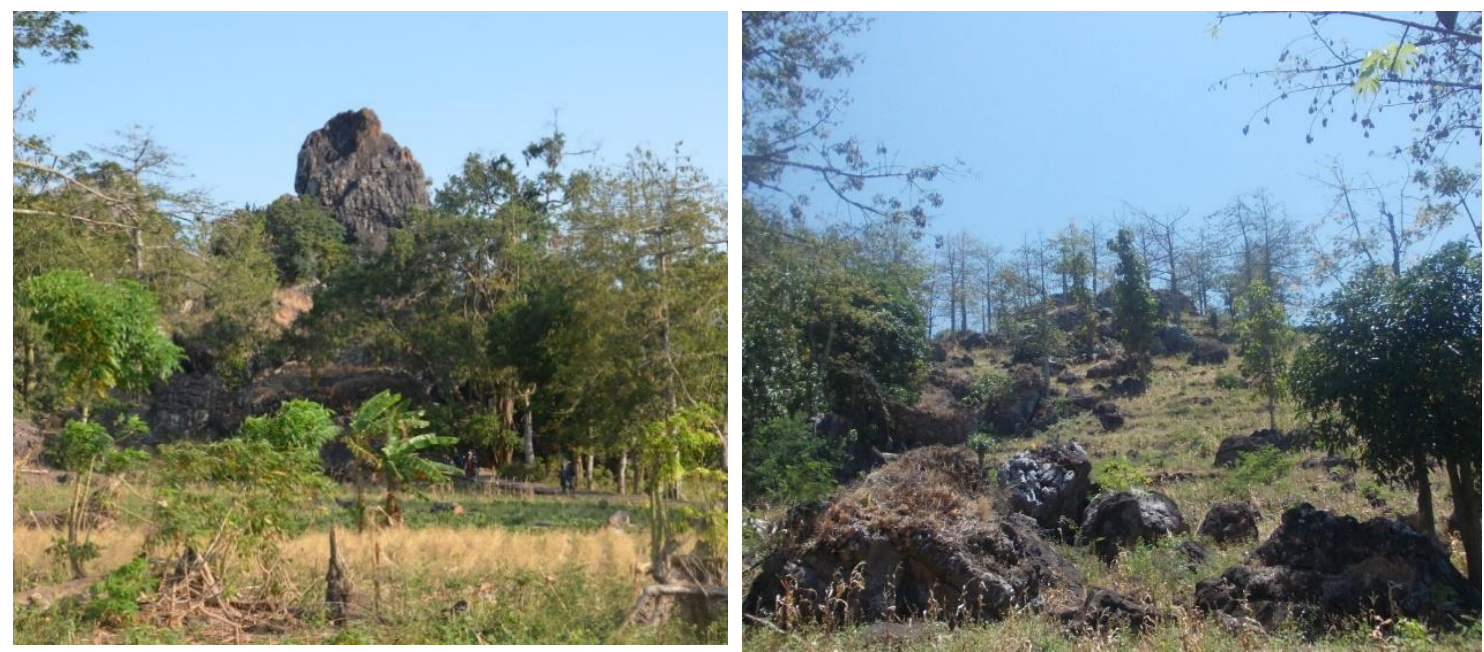

Gambar 4 dan 5. Foto Lokasi Kawasan Batu Ejayya (Kiri) dan sebaran bolder-bolder batuan Vulkanik di sekitar situs (Kanan).

(Sumber: Dokumentasi Balar Sulsel, Tahun 2012)

didominasi oleh batuan Chert. (Hakim dan Suryatman, 2013: 45-52). Penggalian terakhir dilakukan pada tahun 2017 awal dengan menggali di Situs Pangganikang.
Penggalian berukuran 2 x $1 \mathrm{~m}$ hanya dilakukan hingga kedalaman $100 \mathrm{~m}$ karena sebagian besar kotak tertutupi oleh bongkahan vulakanik (gambar 6 dan 7). 


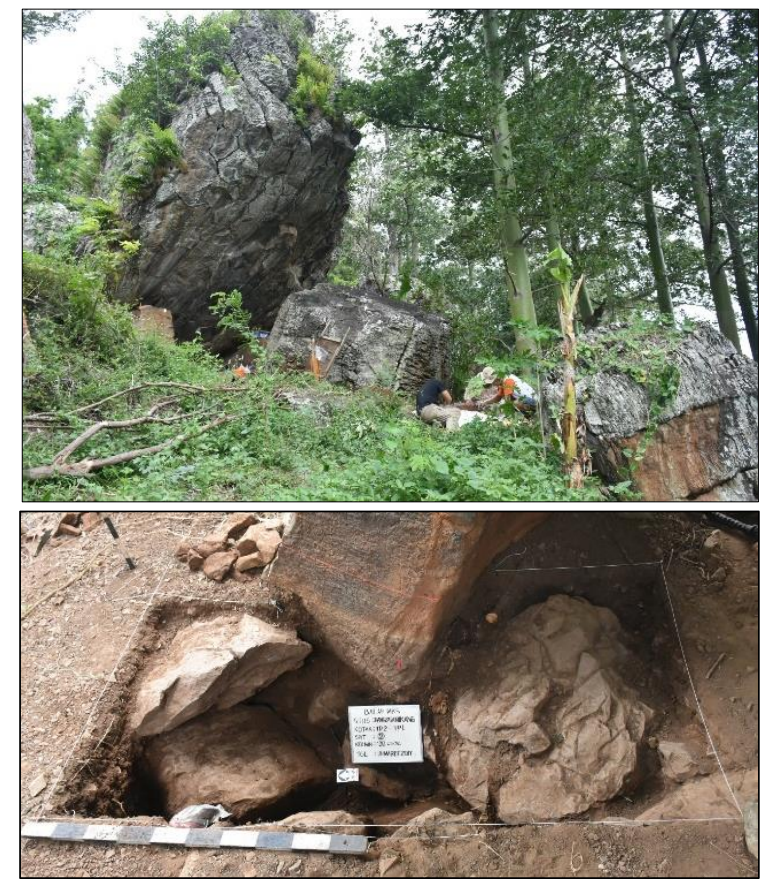

Gambar 6 dan 7. Kondisi di depan Situs Pangganikang (atas). Hasil galian akhir hingga kedalaman $1 \mathrm{~m}$ di Situs Pangnganikang (bawah)

(Sumber: Dokumentasi Balar Sulsel, 2017)

Hasil penelitian hanya menemukan satu layer budaya dengan indikasi temuan berupa serpih dari bahan Chert dan Vulkanik, Lancipan Maros, Mikrolit Berpunggung, Lancipan Tulang, Artefak Kerang, sisa-sisa makanan yang terdiri kerang laut dan tulang binatang. Fragmen tembikar hanya ditemukan pada spit atas (Balar Sulsel, 2017).

\section{Data Analisis Artefak Litik}

Jumlah sampel artefak litik dari temuan survei dan ekskavasi adalah 226 artefak. Sebagian besar berasal dari temuan survei dengan sampel $57.52 \% \quad(\mathrm{n}=130)$ sedangkan lainnya berasal dari temuan ekskavasi di Situs Pangnganikang berjumlah $42.47 \%$ ( $n=96)$. Bahan material Chert paling dominan ditemukan dengan jumlah $79.20 \%$ $(\mathrm{n}=179)$ sedangkan Vulkanik berjumlah $20.80 \%$ ( $n=47)$. Sampel kategori Alat serpih diretus (ASD) berjumlah 23.89\% $(n=54)$ sedangkan kategori Alat Serpih tidak Diretus (ASTD) berjumlah $15.04 \%(n=34)$. Katogori Serpih Utuh (SU) berjumlah $53.98 \%$ $(\mathrm{n}=122)$, sedangkan kategori BI berjumlah $7.08 \%(\mathrm{n}=16)$.

Data ukuran berat pada semua kategori artefak litik menunjukkan bahwa material Chert memperlihatkan kecenderungan ukuran yang lebih kecil dibandingkan bahan material Vulkanik (gambar 8). Pada kategori BI, bahan Chert berukuran berat rata-rata 12.17 gram $(\mathrm{sd}=10.40$, median $=8.44)$ dengan kisaran antara 0.88 hingga 34.4 gram. Bahan Vulkanik jauh lebih besar dengan berat ratarata 237.52 gram $\quad(\mathrm{sd}=316.53$, median=101.5) dengan kisaaran antara 37.08 gram hingga 710 gram (gambar 9). Pada kategori ASD, material Chert hanya berukuran 2.31 gram (sd=1.72) dengan kisaran antara 0.3 hingga 7.86 gram. Bahan Vulkanik jauh lebih besar dengan berat ratarata 7.67 gram $(\mathrm{sd}=5.31)$ dengan kisaran antara 2.4 hingga 15.56 gram.

Pada kategori ASTD, bahan Chert berukuran berat rata-rata 4.77 gram $(\mathrm{sd}=12.37)$ dengan kisaran antara 0.90 hingga 18.22 gram. Bahan Vulkanik lebih berat dengan rata-rata 12.72 gram $(\mathrm{sd}=12.37)$ berkisar antara 4.36 hingga 18.22 gram. Pada kategori SU, bahan Chert juga lebih kecil dengan berat rata-rata 2.37 gram $(\mathrm{sd}=2.73)$ berkisar antara 0.12 hingga 14.46 gram. Bahan Vulkanik berukuran ratarata 8.96 gram $(\mathrm{sd}=6.29)$ dengan kisaran antara1.64 hingga 22.92 gram. Data ini menunjukkan bahwa bahan material berdampak terhadap ukuran pada semua kategori artefak litik yang dihasilkan.

Pada ukuran dataran pukul (DP), tidak ada perbedaan yang signifikan antara kategori ASD, ATD dan SU (gambar 10). Uji statistik metode One Way Anova memperlihatkan nilai yang tidak signifikan, baik pada lebar DP $(\mathrm{df}=2$, f value $=0.94$, $\mathrm{p}-$ value $=0.392\{p>0.05\})$ maupun tebal DP $(\mathrm{df}=2, \quad \mathrm{f} \quad$ value $=0.574, \quad \mathrm{p}$ value $=0.564\{\mathrm{p}>0.05\})$. Ukuran rata-rata lebar DP kategori SU adalah $11.06 \mathrm{~mm}$ (sd=6.27), kategori ASTD 11.95 ( $\mathrm{sd}=4.62)$, 

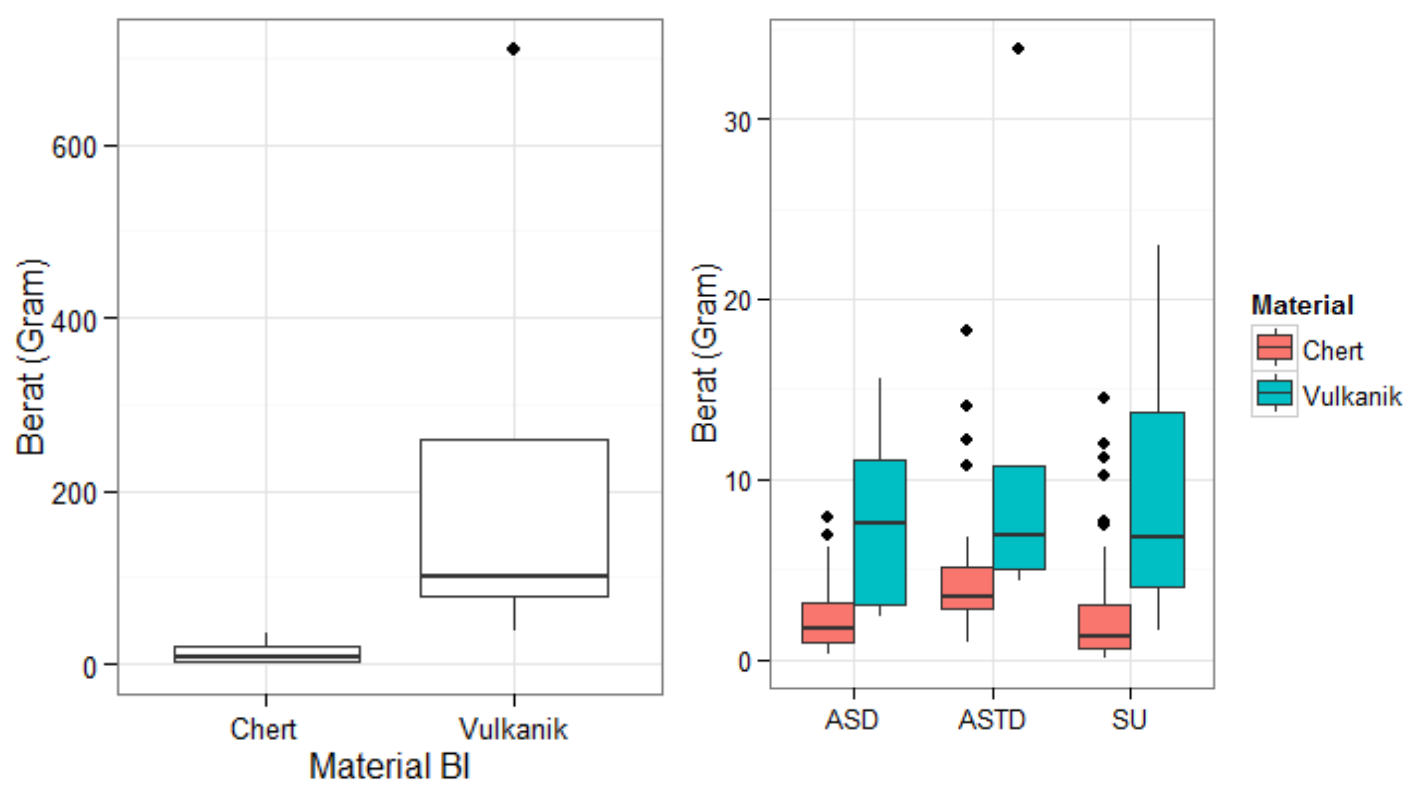

Gambar 8. Perbandingan Berat batu Inti (BI), Alat Serpih Diretus (ASD), Alat serpih tidak Diretus (ASTD) dan Serpih Utuh (SU) pada bahan material Chert dan Vulkanik.

dan kategori ASD $12.53 \mathrm{~mm}(\mathrm{sd}=4.70)$. Ukuran rata-rata tebal DP kategori SU adalah $4.01 \mathrm{~mm}(\mathrm{sd}=2.64)$, ASTD $4.48 \mathrm{~mm}$ $(\mathrm{sd}=2.12)$ dan ASD $3.90 \mathrm{~mm}(\mathrm{sd}=1.98)$.

Perbedaan ukuran DP justru terlihat pada penggunaan bahan material setiap kategori. Bahan Vulkanik berukuran cenderung lebuh besar dibandingkan dengan bahan Chert. Uji statisik metode One Way Anova menunjukkan perbedaan yang signifikan, baik pada ukuran lebar DP $(\mathrm{Df}=1, \mathrm{f}$ value $=56.04, \mathrm{p}<0.001)$, maupun pada tebal $\mathrm{DP}(\mathrm{df}=1, \mathrm{f}$ value $=36.6, \mathrm{p}<0.001)$. Ukuran rata-rata lebar DP bahan Chert adalah $9.97 \mathrm{~mm}(\mathrm{sd}=4.45)$, sedangkan pada bahan Vulkanik adalah $16.62 \mathrm{~mm}(\mathrm{sd}=6.78)$. Ukuran rata-rata tebal DP pada bahan Chert adalah $3.55 \mathrm{~mm}(\mathrm{sd}=2.04)$ sedangkan pada

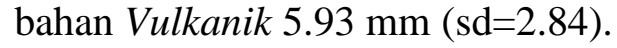

Kategori ASD terdiri dari beberapa tipe alat, yaitu, Lancipan Maros, Mikrolit Berpunggung (BP), Lancipan BP, bilah dan penyerut (gambar 11). Mikrolit BP menunjukkan ukuran yang cenderung paling kecil dengan rata-rata berat 1.01 gram ( $\mathrm{sd}=0.78$ ) dengan jumlah total temuan 11 artefak. Satu diantaranya berasal dari bahan vulknik namun mengalami kerusakan sehingga temuan diaggap tidak sempurna. Temuan mikrolit lainnya berasal dari bahan Chert (gambar 12).

Lancipan Maros dengan jumlah 5 artefak sebagian besar ditemukan dengan proses pengerjaan yang belum sempurna (Calon Alat). Kecenderungan alat berukuran kecil dengan berat rata-rata 1.51 gram $(\mathrm{sd}=0.45)$ berkisar antara 0.82 hingga 1.9 gram. Peretusan pada bagian lateral tampak jelas dilakukan secara bifasial, namun belum ada proses pengerjaan secara intensif pada bagian pangkal. Bahan secara keseluruhan berasal dari Chert. Lancipan BP sedikit lebih besar dibandingkan mikrolit BP dan Lancipan Maros dengan berat rata-rata 2.83 gram $(\mathrm{sd}=1.18)$. Bahan material yang digunakan hanya bahan Chert.

Tipe Penyerut dan Bilah pada kategori ASD menunjukkan ukuran yang cenderung lebih besar dibandingkan tipe lain. Kedua tipe alat ini diretus hanya untuk menghasilkan sisi tajaman yang sudah tumpul, bukan untuk membuat alat dengan pola bentuk tertentu. Tipe bilah hanya 1 sampel berukuran 4.18 gram sedangkan penyerut dengan jumlah 11 sampel berukuran rata-rata 7.47 gram $(\mathrm{sd}=0.87)$. 


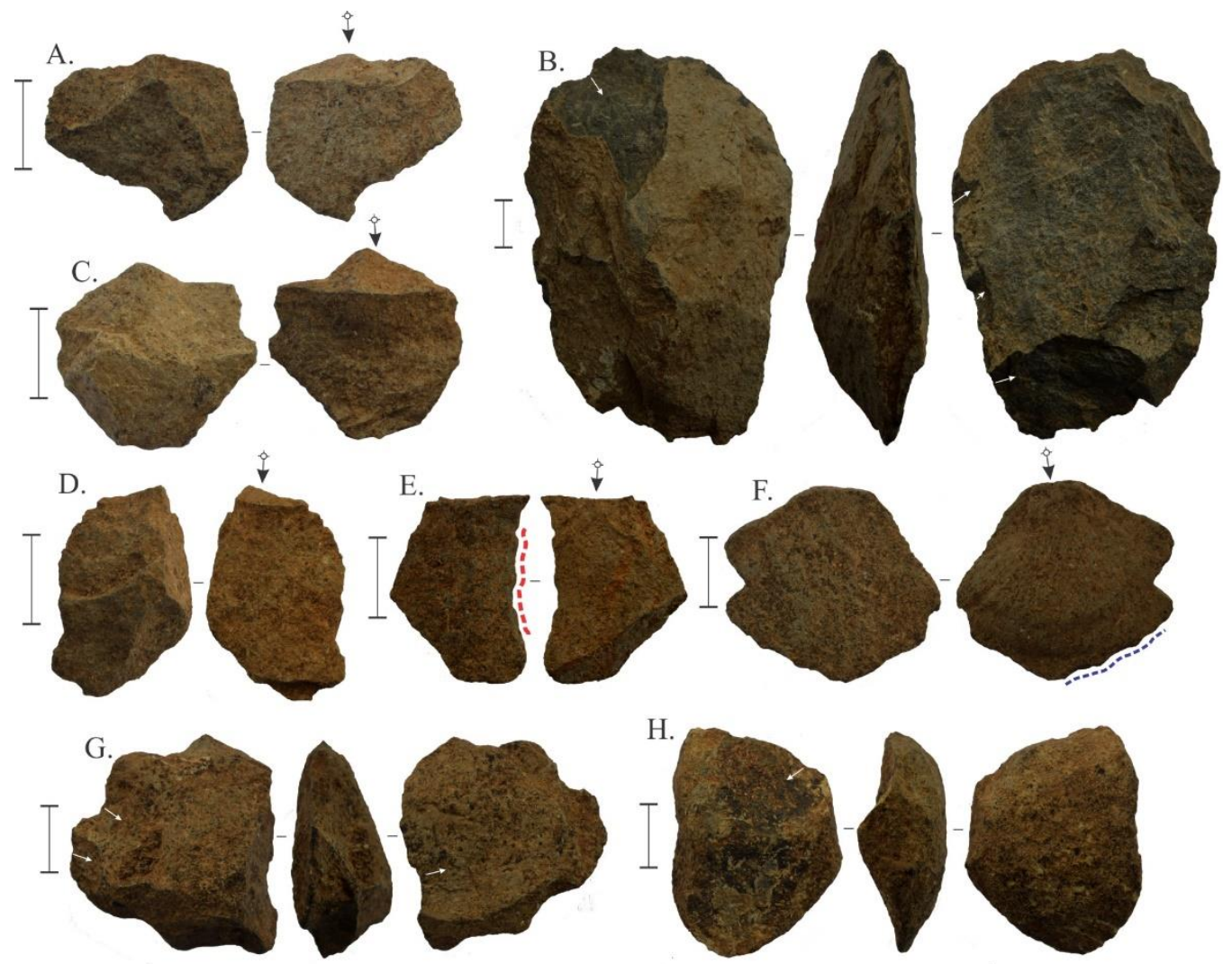

Gambar 9. Artefak litik bahan Vulkanik andesit dari penggalian Situs Pangnganikang. Kategori serpih utuh (SU) kotak TP 2, Spit 9 (A, C dan D). Serpih diretus dari Kotak TP 2, Spit 4 (E). Serpih tidak diretus dengan jejak kerusakan dari Kotak TP 2, Spit 7 (F). Batu inti (BI) dari kotak TP 1, Spit 3 (B) dan kotak TP 2 Spit 9 (G dan H). Skala $2 \mathrm{~cm}$ (Sumber: Dokumentasi Suryatman, Tahun 2017).

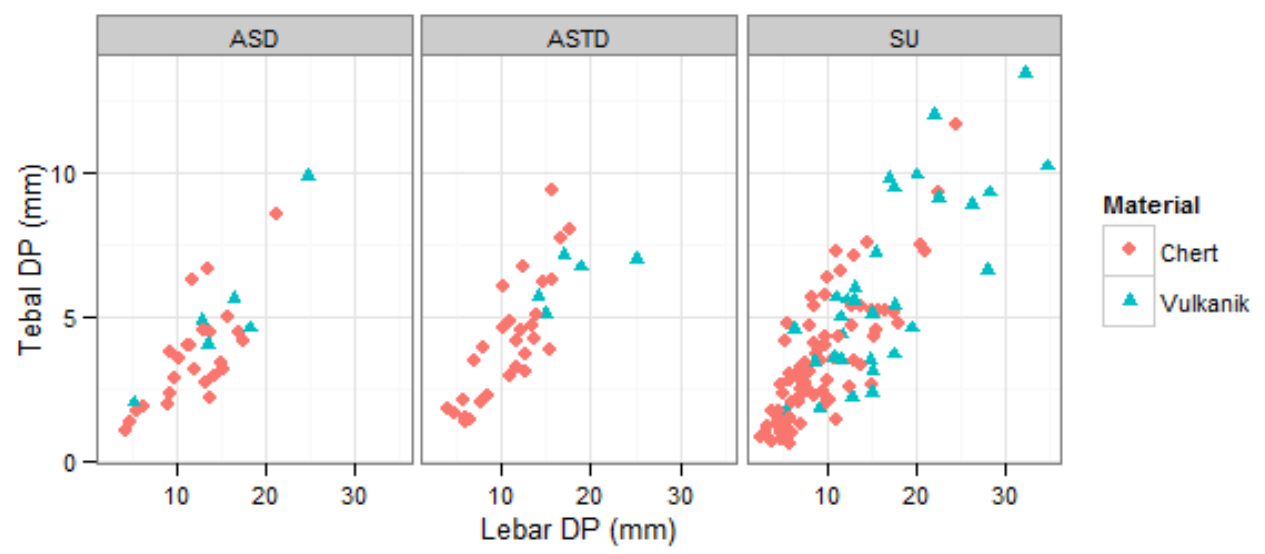

Gambar 10. Diagram pencar perbandingan ukuran tebal dan lebar Dataran Pukul serpih dari kategori ASD, ASTD dan SU. Ada 23 artefak dari kategori ASD tidak memiliki dataran pukul sehingga tidak terkumulasi dalam data.

Tipe Bilah hanya menggunakan bahan Chert sedangkan tipe Penyerut sebagian kecil berasal dari bahan Vulkanik. Alat yang tidak teridentifikasi (TT) menunjukkan ukuran yang cenderung lebih kecil dengan berat rata-rata 1.92 gram $(\mathrm{sd}=0.87)$. Alat ini adalah alat diretus yang mengalami kerusakan pada saat pengerjaan sehingga 

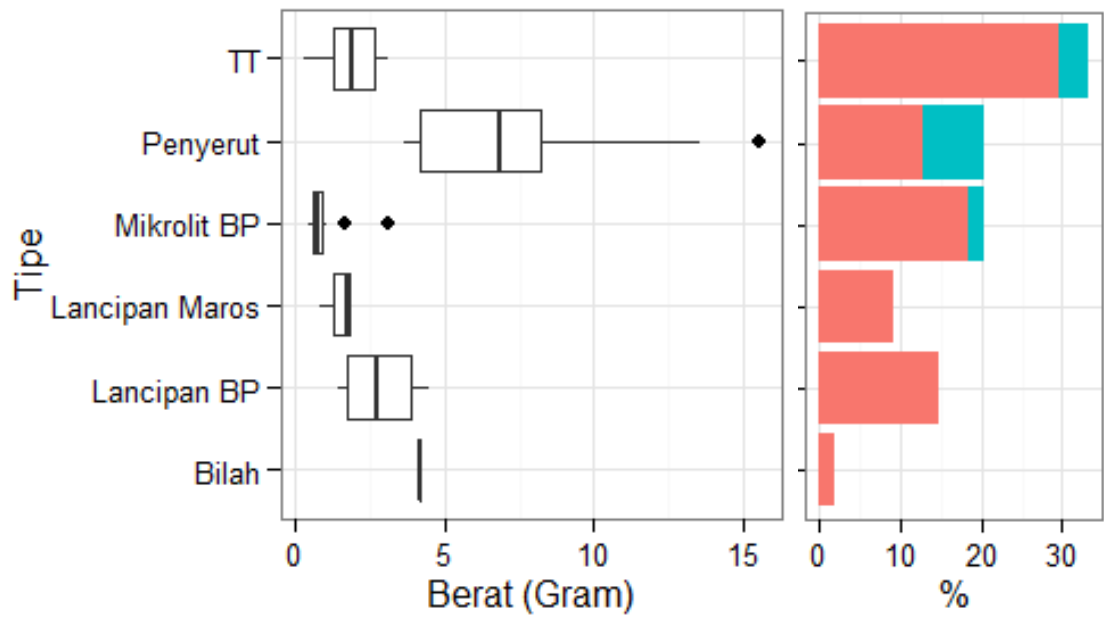

Material

Chert

Vulkanik

Gambar 11. Diagram boxplot perbandingan ukuran berat dan jumlah persentase bahan material kategori ASD dari Kawasan Batu Ejayya
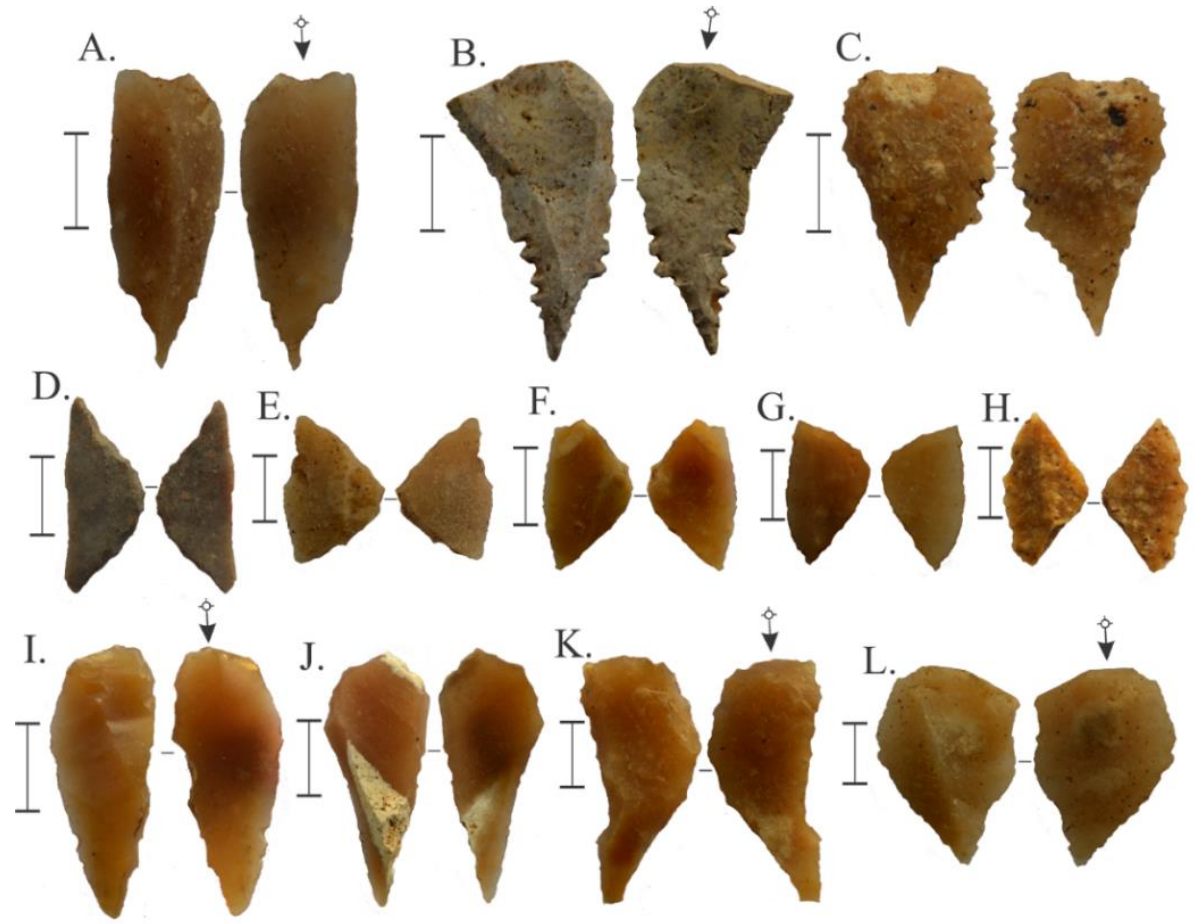

Gambar 12. Alat serpih dimodifikasi (ASD) dari bahan Chert. Tipe Lancipan Maros

belum sempurna dari Situs Pangnganikang (A/TP 1/1) dan C/ TP 1/ TP 2/1, B/Permukaan).

Tipe Mikrolit berpunggung dari Situs Bulu Saraung (D/Permukaan, F/Permukaan, G/Permukaan), Batu Ejayya (E/ Permukaan), dan Pangnganikang (H/Permukaan). Tipe Lancipan Berpunggung dari Situs Bulu Saraung (I/ Permukaan, K/Permukaan), Batu Ejayya (J/Permukaan), dan Pattenungang (L/Permukaan). Skala $1 \mathrm{~cm}$

(Sumber: Dokumentasi Suryatman, Tahun 2017).

sulit diidentifikasi tipe yang ingin dihasilkan.

Kategori ASTD hanya terdiri dari tipe Penyerut dan Bilah (gambar 14). Tipe Penyerut lebih banyak dengan jumlah 25 artefak sedangkan bilah hanya 9 artefak. Penyerut menunjukkan kencenderungan yang lebih besar dengan berat rata-rata 6.7 gram $(\mathrm{sd}=7.12)$ dengan kisaran antara 1.28 hingga 33.86 gram. Tipe bilah menghasilkan 
berat rata-rata 3.52 gram $(\mathrm{sd}=1.70)$ dengan kisaran antara 0.9 hingga 6.46 gram. Sebagian kecil tipe Penyerut berasal dari bahan Vulkanik sedangkan pada tipe bilah hanya berasal dari bahan Chert. Ini menunjukkan bahwa tipe Bilah harus menggunakan batuan Chert, karena untuk menghasilkan alat tersebut dibutuhkan
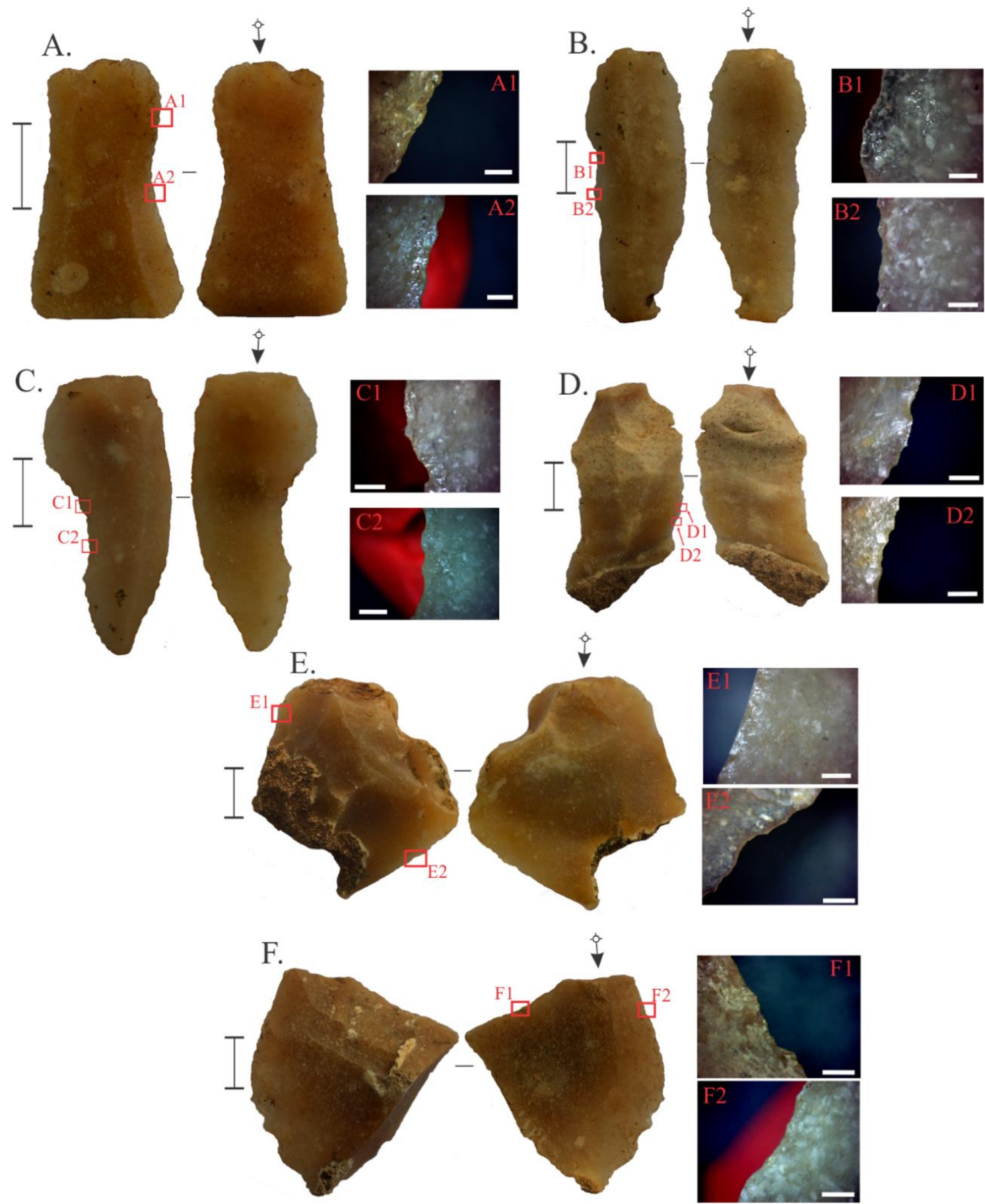

Gambar 13. Alat serpih tidak dimodifikasi (ASTD) tipe Bilah (A, B, C, dan D) dan penyerut (E dan F) dengan indikasi berupa kerusakan pakai (Usewaer) dan kilapan (Gloss) pada sisi tajaman lateral. Artefak ditemukan di permukaan Situs Pattenungang (A, B dan D), Pangnganikang (C dan F) dab Bulu Saraung (E). Skala $1 \mathrm{~cm}$ untuk foto temuan dan skala $1 \mathrm{~mm}$ untuk foto mikro

(Sumber: Dokumetasi Suryatman, Tahun 2017) 

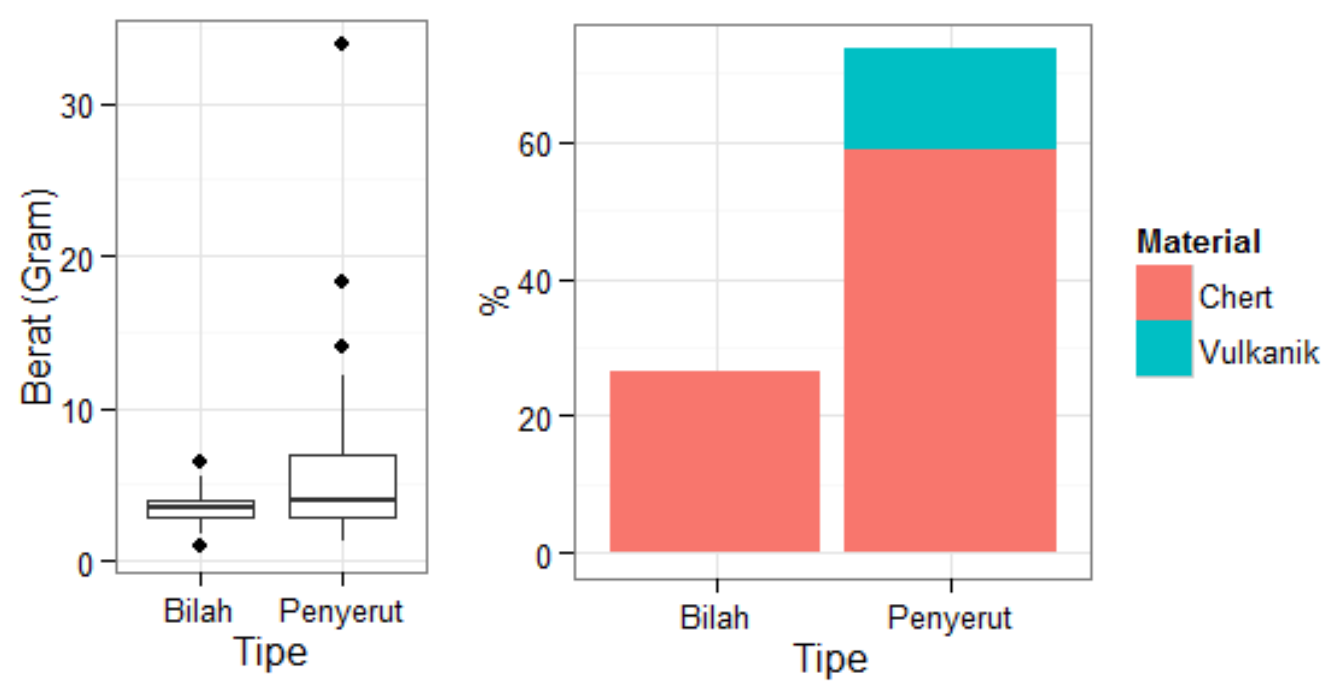

Gambar 14. Perbandingan ukuran berat, jumlah dan bahan material kategori ASTD tipe bilah dan penyerut.

bahan material yang berkualitas baik. Tipe Bilah diserpih dengan pola penyerpihan yang tersistematis.

Beberapa kategori ASTD menunjukkan indikasi kerusakan tajaman dan kilapan (Gloss) pada sisi tajaman alat (gambar 13). Kehadiran kilapan menunjukkan bahwa alat digunakan untuk mengolah bahan vegetasi seperti bambu dan daun-daunan. Penggunaan bambu berperan penting dalam ekonomi masyarakat prasejarah di daerah tropis, terutama di Asia Tenggara. Beberapa data etnografi masyarakat pemburu dan pengumpul makanan, seperti orang Mentawai di Pulau Siberut Sumatra Barat dan orang Agta di Pulau Luzon Filipina, menggunakan bambu atau kayu keras sebagai peralatan hidup (Foristier, 2007: 35-37).

Kategori BI sulit ditemukan dipermukaan situs, terutama bahan Chert. Total sampel BI seluruhnya hanya 16 artefak, dimana 12 artefak dari bahan Chert dan 4 artefak dari bahan Vulkanik. Teknik penyerpihan pada Batu Inti pada umumnya dilakukan secara acak, terutama pada batuan Vulkanik. Beberapa diantaranya dipangkas dengan penyerpihan searah. 5 sampel kategori BI menunjukkan tipe penyerpihan bipolar.
BI tipe bipolar menunjukkan ukuran kecil dengan rata-rata berat rata-rata hanya 3.14 gram $(\mathrm{sd}=1.6)$ dengan kisaran antara 8.24 hingga 5.12 gram. Tipe ini hanya digunakan pada batuan Chert. Teknik bipolar (gambar 15A, 15B, 15C dan 15D) biasanya digunakan sebagai strategi untuk menyerpih batu inti berukuran kecil (Hiscock, 2015: 37-41). Mereka menggunakan pelandas (Anvil) untuk menyerpih sehingga menghasilkan tekanan dan luka pukul dari dua arah berlawanan. Batu inti berasal dari serpih besar, diserpih dengan cara dipukul pada sisi ventral atau dorsal (Blow to Face) untuk menghasilkan serpih rusak berukuran kecil. Serpih rusak selanjutnya dipangkas pada bagian tepian (Blows to Edge) dengan teknik bipolar (Moore et al., 2009: 503-523).

Jumlah pelepasan serpih (Flake Scars) pada kategori BI hanya menghasilkan rata-rata 4 kali $(\mathrm{sd}=2.5)$ dengan kisaran antara 1 hingga 12 kali penyerpihan. Panjang pelepasan serpih pada batu Inti (PBI) berukuran rata-rata $20.16 \mathrm{~mm}(\mathrm{sd}=11.34)$ dengan kisaran antara $7.92 \mathrm{~mm}$ hingga 59.66 $\mathrm{mm}$. Perbedaan kecenderungan ukuran panjang PBI, ASD, ASTD dan SU pada bahan Chert dengan Vulkanik terlihat signifikan (gambar 16 dan tabel 1). 

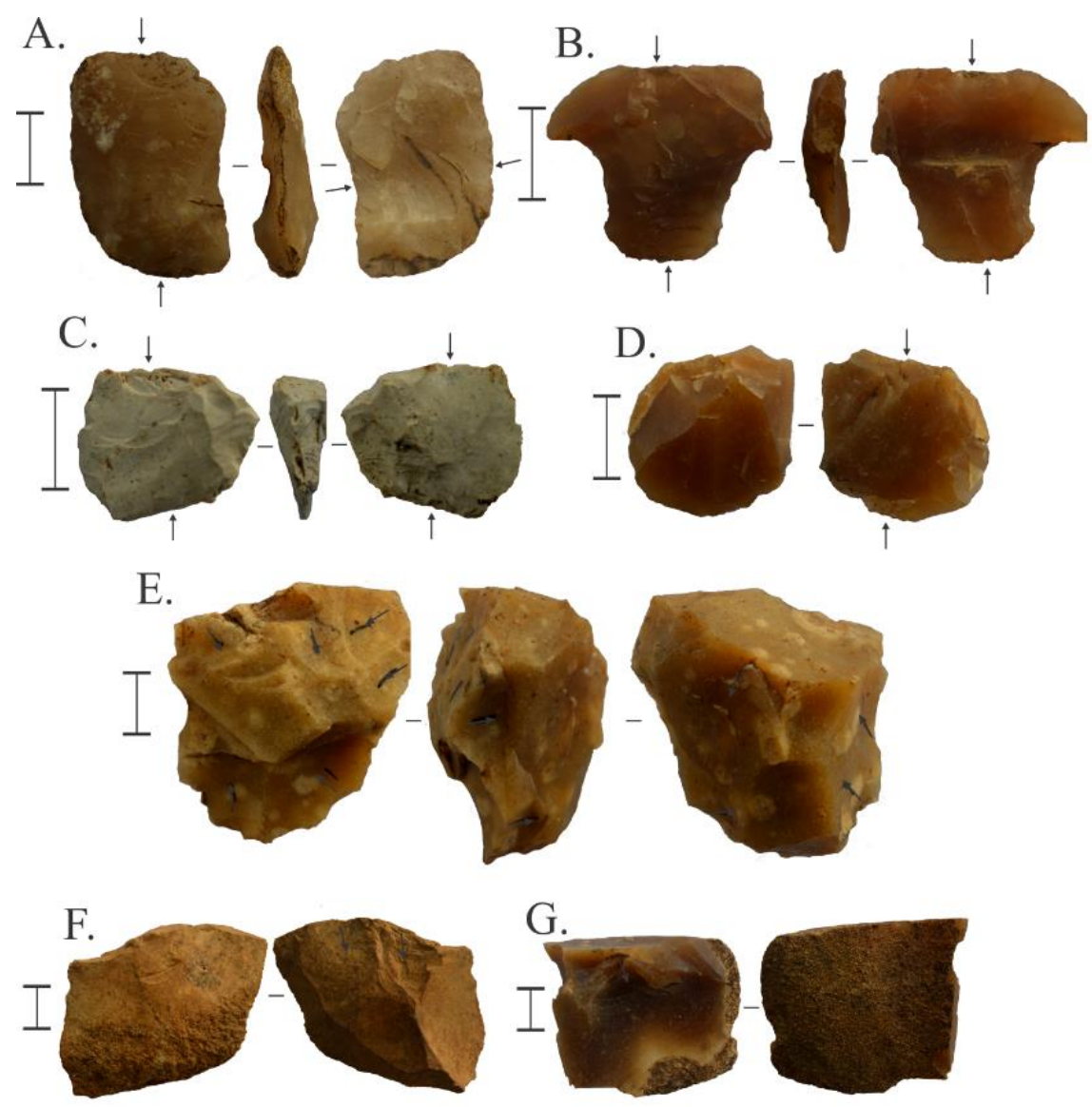

Gambar 15. BI Bipolar dari Situs Bulu Saraung (A/Permukaan), Pattenungang (B/Permukaan), Panganreang Tudea (D/Permukan), dan Pangnganikang (C/TP2/1). BI dengan teknik penyerpihan acak dari Situs Panganreang Tudea (E/Permukaan). BI dengan penyerpihan searah dari Situs Bulu Saraung (F/Permukaan) dan Situs Pattenungang (G/Permukaan). Skala $1 \mathrm{~cm}$

(Sumber: Dokumentasi Suryatman, Tahun 2017).

Pada batuan Vulkanik

kecenderungan ukuran panjang pada semua kategori cenderung sama, walaupun panjang kategori PBI lebih heterogen. Uji statistik menggunakan metode One way Anova menunjukkan bahwa tidak ada perbedaan yang signifikan rata-rata ukuran panjang pada semua kateori $(\mathrm{df}=2$, $\mathrm{f}$ value $=0.155$, $\mathrm{p}$ value $=0.926\{p>0.05\})$. Pada bahan Chert, uji statistik menggunakan metode One way Anova justru menunjukkan perbedaan yang signifikan $\quad(\mathrm{sd}=3, \mathrm{f} \quad$ value $=30.99, \quad \mathrm{p}-$ value $<0.001\{p<0.05\})$. Kategori PBI jauh lebih kecil dibandingkan kategori lain. Kategori SU lebih kecil dan heterogen dibandingkan kedua kategori alat serpih.

Penjelasan data ini menunjukan bahwa penyerpihan awal untuk batuan Chert dan Vulkanik diduga kuat dilakukan pada tempat yang berbeda. Pada batuan Vulkanik cenderung dilakukan di sekitar kawasan situs. Tidak ada perbedaan antara serpih, alat serpih dan panjang pelepasan serpih pada Batu Inti. Namun untuk bahan Chert, penyerpihan awal dilakukan di luar dari kawasan situs, terutama untuk menghasilkan serpih panjang, dan serpih-serpih berbentuk bilah. Diduga kuat, penyerpihan tidak jauh dari lokasi pengambilan bahan material Chert. Korteks yang umumnya masih melekat pada artefak Chert tidak mengalami pembudaran, kasar dan lapuk. Ini menunjukkan bahwa bahan Chert bukan berasal dari sungai, tetapi diambil langsung di wilayah pegunungan.

Serpih Chert berukuran besar dan berbentuk bilah di bawah ke kawasan situs 
Tabel 1. Ringkasan statistik data ukuran Panjang $(\mathrm{mm})$ antara Pelepasan serpih pada batu Inti (PBI), Alat serpih Diretus (ASD), Alat Serpih tidak Diretus (ASTD), dan Serpih utuh (SU) pada setiap bahan material Chert dan Vulkanik

\begin{tabular}{cccccccccc}
\hline $\begin{array}{c}\text { Bahan } \\
\text { Material }\end{array}$ & $\begin{array}{c}\text { Variabel } \\
\text { Data }\end{array}$ & $\begin{array}{c}\text { Rata- } \\
\text { rata }\end{array}$ & SD & IQR & Min-Maks & Q1 & Q2 & Q3 & N \\
\hline Chert & ASD & 26.30 & 6.87 & 9.86 & $13.34-42.07$ & 21.39 & 25.64 & 31.25 & 47 \\
\cline { 2 - 10 } & ASTD & 33.87 & 9.66 & 15.39 & $17.87-53.03$ & 27.16 & 31.94 & 42.55 & 29 \\
\cline { 2 - 10 } & SU & 22.36 & 9.09 & 13.59 & $7.57-47.7$ & 15.55 & 20.65 & 29.14 & 91 \\
\cline { 2 - 9 } Vulkanik & PBI & 16.55 & 5.63 & 6.09 & $7.92-37.52$ & 13.10 & 15.13 & 19.19 & 50 \\
\cline { 2 - 9 } & ASD & 38.58 & 7.16 & 8.66 & $28.71-49.24$ & 34.44 & 37.03 & 43.1 & 7 \\
\cline { 2 - 9 } & ASTD & 35.57 & 11.83 & 8.17 & $24.74-55.15$ & 28.89 & 32 & 37.06 & 5 \\
\cline { 2 - 9 } & SU & 35.73 & 7.97 & 13.14 & $22.8-49.19$ & 28.69 & 35.36 & 41.82 & 31 \\
\hline & PBI & 36.57 & 15.95 & 26.11 & $15.73-59.66$ & 23.83 & 34.51 & 49.94 & 11 \\
\hline
\end{tabular}

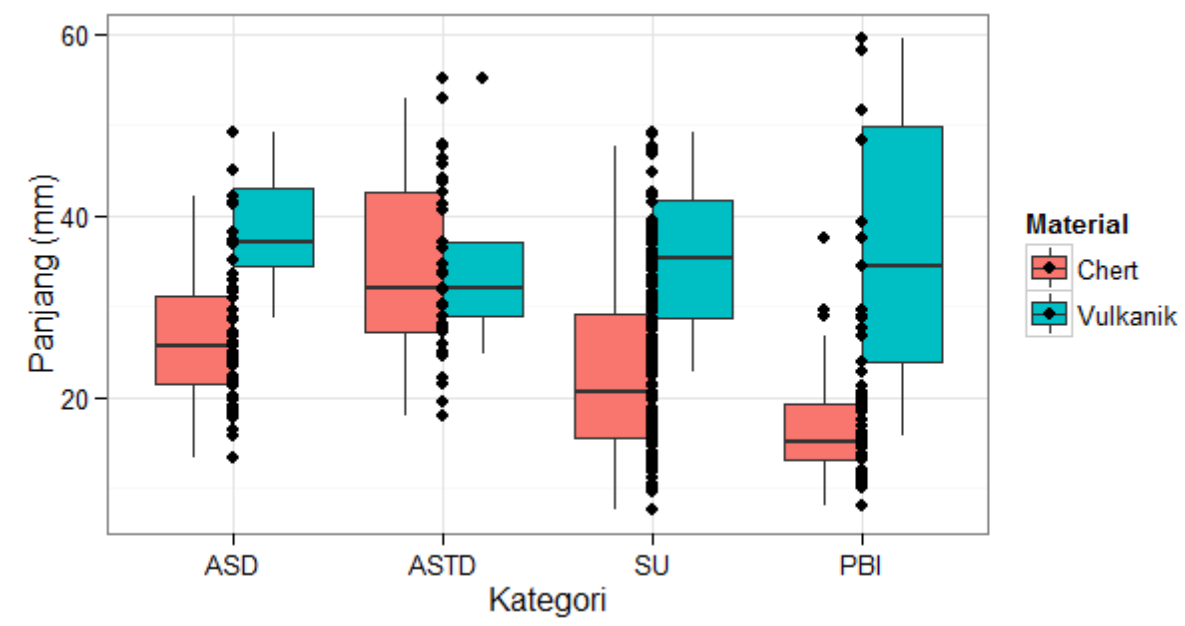

Gambar 16. Diagram boxplot perbandingan antara panjang Pelepasan serpih pada Batu Inti (PBI) dengan Alat serpih Diretus (ASD), Alat serpih tidak Diretus (ASTD) dan Serpih Utuh (SU) pada setiap bahan material.

untuk diproses ulang agar dapat dijadikan peralatan. Beberapa serpih yang tidak membutuhkan pengerjaaan lanjutan, terutama bilah, dapat langsung digunakan. Beberapa diantaranya juga akan dikerja ulang (Secondary Working) untuk menghasilkan serpih-serpih berukuran kecil. Serpih tersebut dimodifikasi untuk tipe-tipe alat berukuran kecil, seperti Lancipan Maros dan Mikrolit. Berberapa serpih bilah panjang dapat dimodifikasi untuk menghasilkan tipe tertentu seperti Lancipan Berpunggung.

\section{Interpretasi Teknologi}

Hasil analisis menunjukkan bahwa penghuni Toalian di Kawasan Batu Ejayya menggunakan bahan Chert dan Vulkanik untuk membuat peralatan. Bahan Chert masih menjadi bahan utama walapun bahan tersebut tidak tersedia di sekitar kawasan situs. Kebutuhan peralatan kecil yang cenderung tinggi mengharuskan mereka mencari bahan tersebut sebagai bahan utama. Bahan Vulkanik hanya bahan alternatif untuk peralatan berukuran besar yang tidak membutuhkan modifikasi tinggi.

Kedua bahan material menunjukkan tahapan teknologi yang berbeda (gambar 17). Bahan Chert memperlihatkan tahapan teknologi yang panjang dan rumit dibandingkan Vulkanik. Penyerpihan awal untuk bahan Chert dilakukan dil luar kawasan situs. Diduga lokasi tersebut tidak jauh dari sumber bahan material, di sekitar 


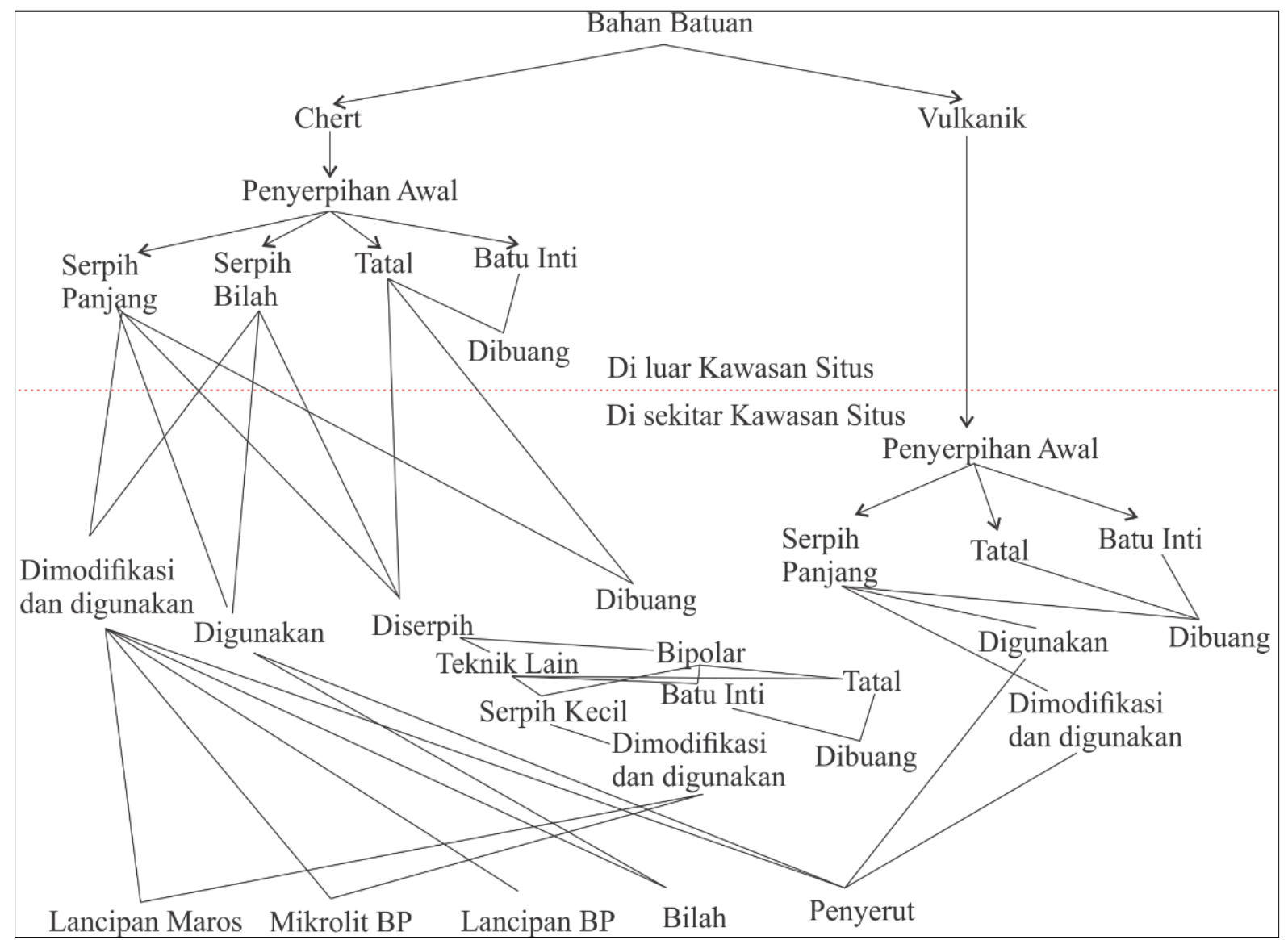

Gambar 17. Sistematika tahapan teknologi artefak litik Toalian di Kawasan Prasejarah Batu Ejayya (Sumber: Dokumentasi Suryatman, Tahun 2017).

daerah pegunungan. Penyerpihan awal akan menghasilkan serpih berukuran panjang, serpih bilah, batu inti dan tatal. Batu inti dari hasil penyerpihan awal akan dibuang di lokasi pertama, sedangkan tatal berukuran besar sebagian akan di bawah ke kawasan situs.

Serpih panjang, serpih bilah dan beberapa tatal dari bahan Chert akan di bawah ke kawasan situs untuk diproses kembali. Sumber bahan yang jauh dari lokasi hunian menjadi alasan mendasar mereka tidak membawa bahan material berukuran besar ke situs. Beberapa serpih panjang dan bilah dapat digunakan langsung sebagai alat pemotong apabila bentuk tajaman dianggap efektif. Serpih yang mengalami penumpulan akibat penggunaan akan diretus kembali untuk memperoleh tajaman. Sebagian serpih bilah akan dimodifikasi dengan cara diretus untuk menghasilkan tipe peralatan tertentu seperti Lancipan Berpunggung.

Sebagian serpih-serpih panjang akan diserpih ulang dengan teknik bipolar untuk menghasilkan serpih-serpih yang lebih kecil. Kebutuhan peralatan kecil dibarengi dengan keterbatasan bahan material Chert di sekitar situs mengharuskan mereka menerapkan teknik ini. Tatal berukuran besar akan diserpih ulang dengan cara digenggam untuk menghasilkan serpih-serpih kecil. Serpih tersebut akan dimodifikasi untuk membuat peralatan kecil seperti Lancipan Maros dan Mikrolit Berpunggung.

Bahan Vulkanik menunjukkan tahapan teknologi lebih simpel dibandingkan Chert. Bahan ini tersedia di sekitar situs sehingga penyerpihan awal dapat dilakukan tidak jauh dari kawasan situs. Penyerpihan awal hanya menghasilkan 
serpih panjang, tatal dan batu inti. Bahan ini sulit menghasilkan serpih-serpih berbentuk bilah. Dibutuhkan bahan berkualitas seperti Chert karena pola penyerpihan untuk menghasilkan bilah harus dilakukan secara sistematis.

Serpih-serpih panjang dari bahan Vulkanik dapat digunakan langsung sebagai alat pemotong apabila menghasilkan tajaman yang efektif. Peretusan pada sisi tajaman dapat dilakukan kembali apabila mengalami penumpulan. Ada upaya mereka untuk membuat peralatan kecil dari bahan Vulkanik namun terlihat cenderung mengalami kegagalan.

\section{PENUTUP}

Batu Ejayya adalah kawasan prasejarah yang dihuni oleh manusia pendukung budaya Toalian di bagian pesisir selatan Sulawesi. Kawasan tersebut mulai dihuni pada pertengahan hingga akhir holosen. Kawasan ini jauh dari himpunan situs lain dan menunjukkan formasi geologi yang berbeda dengan situs-situs lain di bagian barat daya tengah Sulawesi Selatan. Keterbatasan bahan Chert di sekitar wilayah Batu Ejayya akan berdampak terhadap perilaku penghuni Toalian untuk bertahan hidup di bagian selatan Sulawesi.

Bahan Chert masih menjadi bahan utama dalam teknologi artefak litik di kawasan Batu Ejayya. Desakan kebutuhan peralatan kecil mengharuskan mereka untuk mencari serta menemukan sumber tersebut di luar dari kawasan situs. Walaupun demikian bahan Vulkanik tetap digunakan sebagai bahan aternatif untuk peralatan yang tidak membutuhkan modifikasi tinggi.

Hasil analisis teknologi menunjukkan bahwa bahan Chert memiliki tahapan teknologi yang lebih panjang dan rumit dibandingkan dengan bahan Vulkanik. Tahapan untuk bahan Chert diawali dengan penyerpihan awal yang dilakukan jauh dari kawasan situs. Beberapa serpih panjang dari hasil pemangkasan awal akan dibawah ke situs untuk diproses lebih lanjut.

\section{Ucapan Terima Kasih}

Data yang digunakan dalam tulisan ini adalah hasil penelitian dari anggaran Balar Sulsel, Kementerian Pendidikan dan Kebudayaan pada tahun 2012, 2013 dan 2017. Ucapan terima kasih sebesar-besarnya disampaikan kepada Drs. I Made Geria, M.Si, selaku Kepala Pusat Penelitian Arkeologi Nasional dan M. Irfan Mahmud, M.S.i, selaku Kepala Balar Sulsel. Ucapan terima kasih juga disampikan kepada Bapak Budianto Hakim selaku ketua tim pelaksanaan penelitian di Kawasan Batu Ejayya. Selanjutnya, ucapan terima kasih juga saya sampaikan kepada Muh. Nur, Andi Muh. Syaiful dan ratno Sardi selaku anggota tim dan juga hasil diskusinya sehingga dapat menghasilkan gagasan yang baik pada penelitian ini. 


\section{DAFTAR PUSTAKA}

Andrefsky, W., Jr. 2005. Lithics: Macroscopic Approacher to Analysis. Cambridge: Cambridge University Press.

Balar Sulsel, 2012. Laporan Penelitian Arkeologi di Kawasan Batu Ejayya, Kecamatan Bissappu, Kabupaten Bantaeng: Interpretasi Fase Hunian dan Perubahan Teknologi pada Situs Batu Ejayya. Tidak Terbit.

, 2013. Laporan Penelitian Arkeologi Tahap II di Kawasan Batu Ejayya, Kecamatan Bissapu, Kabupaten Bantaeng. Tidak Terbit.

, 2017. Laporan Penelitian Arkeologi di Situs Pangngainakang, Kawasan Batu Ejayya, Kecamatan Bissappu, Kabupaten Bantaeng. Tidak Terbit.

Bellwood, P., 2007. Prehistory of the Indo-Malaysian Archipelago. Sydney: ANU E Press.

Bulbeck, D., 1992. A Tale of Two Kingdom: the historical archeology of Gowa Tallok, South Sulawesi, Indonesia. Ph. D. diss. Camberra: Australian National University.

Bulbeck, D., Pasqua, M. dan Di Lello, A., 2000. "Culture History of the Toalean of South Sulawesi, Indonesia”. Asian Perspectives, 39: 71-108.

Forestier, H., 2007. Ribuan Gunung Ribuan Alat Batu: Prasejarah Song Keplek Gunung Sewu, Jawa Timur. Kepustakaan Popules Gramedia, Ecole francaise d'Extreme-Orient Institut de Recherche pour le Developpement dan Pusat Penelitian dan Pengembangan Arkeologi Nasional. Forum jakarta-Paris.

Glover, I.C., 1976. "Ulu Leang Cave, Maros: a Premilinary Sequance of post Pleistocene cultural development in South Sulawesi”. Archipel, 11: 54-113.

, 1978. "Survey and Excavation in The Maros District, South Sulawesi, Indonesia: The 1975 Field Saeson”. Bulletin of the Indo-Pacific Prehistory Association. 1:113154.

Hakim, B. dan Suryatman 2013. "Stone Tools technology and occupation phases at Batu Ejayya, South Sulawesi”. Review of Indonesian and Malaysian Affairs, 47: 47-62

Heekeren HR. van, 1972. The Stone Age of Indonesia. 2nd ed. The Hague: Martinus Nijhoff.

Hiscoock, P., 2007. "Looking the Other Way: A Materialist/Technological Approach to Classifying Tools and Implements Cores and Retouched Flakes". In Tools versus Cores Alternative Approached to Stone Tool Analysis, edited Shannon P. McPherron. Cambridge: Scholars Publishing 
, 2015. "Making is small in the Paleolithic: bipolar stone-working, miniature artefacts anf models of core recycling". World Archaeology, no. February: 37-41.

Moore, W. M., Sutikna, T., Jatmiko, Morwood, M. J. dan Brumm, A., 2009. "Continuities in Stone Artefact Technology at Liang Bua, Flores, Indonesia”. Journal of Human Evolution, 57: 503-526.

Pasqua, M., 1995. Mid-late holosen Toelaean Sites in South Sulawesi: A Technological Analysis. Submitted in Partial Fulfiment of the requirement for the degree of bachelor of Science (Honours). Centre for Archaeology, University of Western Australia.

Soejono, R.P, 1984. Sejarah Nasional Indonesia I. Balai Pustaka Departemen Pandidikan dan Kebudayaan. 